\title{
Whole Organism
}

National Cancer Institute

\section{Source}

National Cancer Institute. Whole Organism. NCI Thesaurus. Code C13413.

Considering the organism as a whole 